\title{
Physicochemical analysis of frankfurter type sausages made with red tilapia fillet waste (Oreochromis sp) and quinoa flour (Chenopodium quinoa W.)
}

\author{
Análise físico-química de salsichas tipo frankfurt feitas com resíduos de filé de tilápia \\ vermelha (Oreochromis sp.) e farinha de quinoa (Chenopodium quinoa W.)
}

\author{
José Igor Hleap Zapata ${ }^{1 *}$, Gloria Carmenza Rodríguez de la Pava² \\ ${ }^{1}$ National University of Colombia, Faculty of Engineering and Management, Department of Engineering, Palmira, Valle del Cauca - Colombia \\ 2 University of San Buenaventura, Faculty of Engineering, Cali, Valle del Cauca - Colombia
}

\section{*Corresponding Author}

José Igor Hleap Zapata, National University of Colombia, Faculty of Engineering and Management, Department of Engineering, Carrera 32, No. 12-00, Palmira, Valle del Cauca - Colombia, e-mail: jihleapz@unal.edu.co

\begin{abstract}
Cite as: Physicochemical analysis of frankfurter type sausages made with red tilapia fillet waste (Oreochromis sp) and quinoa flour (Chenopodium
\end{abstract} quinoa W.). Braz. J. Food Technol., v. 21, e2016103, 2018.

Received: Aug. 11, 2016; Accepted: July 31, 2017

\section{Abstract}

In Colombia, the production of red tilapia (Oreochromis sp) has shown important development in recent years. It is a hydro-biological resource that generates fish fillet waste that can be used in the manufacture of fish products. The aim of this research was to analyze the influence of quinoa flour on the physicochemical properties, texture and oxidative stability during storage and sale of Frankfurter sausages made with red tilapia fillet waste when adding two concentrations of quinoa flour, $10 \mathrm{~g} / \mathrm{kg}$ and $20 \mathrm{~g} / \mathrm{kg}$, and a control treatment with no quinoa flour. The sausages were vacuum packed and stored under refrigeration $\left(2^{\circ} \mathrm{C} \pm 2{ }^{\circ} \mathrm{C}\right)$. The proximate chemical composition, $\mathrm{pH}, \mathrm{CIElab}$ coordinates, lipid oxidation, water holding capacity, water binding ability and cooking yield were determined, along with an instrumental texture analysis for each of the sausages prepared. The addition of quinoa flour at a concentration of $10 \mathrm{~g} / \mathrm{kg}$ presented the best water holding capacity, water binding ability, lighter coloration and cooking yield, as compared to the control sausage. By contrast, the sausages with $20 \mathrm{~g} / \mathrm{kg}$ were harder and required greater effort to cut than the control $(p<0.05)$. The addition of quinoa flour increased fat oxidation after 6 days of monitoring. The addition of $10 \mathrm{~g} / \mathrm{kg}$ of quinoa flour was the best concentration for the production of sausages made with red tilapia fillet waste, which represents a new alternative for hydro-biological-origin foodstuffs.

Keywords: Aquaculture; Nutrition; Fishing industry; Fish products; Non-meat extenders.

\section{Resumo}

Na Colômbia, a produção de tilápia vermelha (Oreochromis sp.) tem alcançado avanços importantes no últimos anos. A tilápia é um recurso hidrobiológico que gera resíduos a partir do seu filetamento, os quais podem ser usados na fabricação de produtos pesqueiros. O objetivo desta pesquisa foi analisar a influência da farinha de quinoa nas propriedades físico-químicas, na textura e na estabilidade oxidativa ao usar duas concentrações de farinha de quinoa, $10 \mathrm{~g} / \mathrm{kg}$ e $20 \mathrm{~g} / \mathrm{kg}$, além de um tratamento controle sem adição de farinha de quinoa, em salsichas tipo Frankfurt feitas com resíduos do filetamento de tilápia vermelha, durante a sua armazenagem e comercialização. As salsichas foram embaladas a vácuo e armazenadas sob refrigeração $\left(2{ }^{\circ} \mathrm{C} \pm 2{ }^{\circ} \mathrm{C}\right)$. Foi determinada a composição centesimal, o valor de $\mathrm{pH}$, as coordenadas de CIElab, a oxidação lipídica, a capacidade de retenção de água, a capacidade de absorção de água e o rendimento no cozimento, além de uma análise instrumental da textura para cada uma das salsichas. A salsicha com adição de farinha de quinoa a uma concentração de $10 \mathrm{~g} / \mathrm{kg}$ apresentou os melhores valores na capacidade de retenção de água, na capacidade de absorção de água, na coloração mais clara e no rendimento no cozimento, quando comparada com as salsichas controle. Por outro lado, as salsichas com $20 \mathrm{~g} / \mathrm{kg}$ apresentaram maior dureza e precisaram maior esforço ao corte que as salsichas controle $(p<0,05)$. A adição de farinha de quinoa aumentou o grau de oxidação das gorduras depois de seis dias de 
Physicochemical analysis of frankfurter type sausages made with red tilapia fillet waste (Oreochromis $s p$ ) and quinoa flour (Chenopodium quinoa W.)

Zapata, J. I. H.; Pava, G. C. R.

monitoração. A adição de $10 \mathrm{~g} / \mathrm{kg}$ de farinha de quinoa foi a melhor concentração na produção de salsichas feitas com resíduos do filetamento de tilápia vermelha, o que se apresenta como uma nova alternativa para a elaboração dos alimentos de origem hidrobiológica.

Palavras-chave: Aquicultura; Nutrição; Indústria pesqueira; Produtos pesqueiros; Extensores não cárneos.

\section{Introduction}

In Colombia resources of hydro-biological origin, in particular those produced by aquaculture, have reached significant levels of development, with growth comparable to the global growth for this activity, averaging $13 \%$ annually over the past 27 years. In 2013 this represented $51.4 \%$ of the total fish production in Colombia, making this country sixth in terms of importance for aquaculture in Latin America (AUNAP, 2013). Aquaculture in Colombia has focused on the production of red (Oreochromis sp.) and silver tilapia (Oreochromis niloticus) (58.5\%), cachama (Colossoma macropomum) (19.25\%), trout (Oncorhynchus mykiss) (6.8\%), other native and exotic continental species (5.04\%), cobia (Rachycentron canadum) (0.13\%) and shrimp (Penaus vannamei) (10.3\%) (AUNAP, 2013). In Colombia, tilapia production is basically dedicated to the export of fresh and frozen fillets, with some local consumption of fillets and whole eviscerated tilapia in some processed products, such as burgers, steak, sausages and nuggets (FEDEACUA, 2015).

When making these products, mainly when filleting the fish, the fillets are subjected to an adaptation process which consists of the elimination of the parts that exceed the size and presentation stipulated for commercialization. These trimmings or wastes represent a significant volume of protein-rich raw material, which usually ends up discarded or sold at non-competitive prices. This study aimed to provide a better use for these by-products through the development of a commercial product such as frankfurter type sausages, made from a raw material of hydro-biological origin.

The frankfurter type sausage, made from beef, pork, chicken or meat mixtures, with the addition of different ingredients and flavourings, including extenders or binders, is a widely accepted product in Colombia. Although little research has been done on tilapia sausages, there are some articles, such as the one published by Tayel (2016), in which a microbiological analysis of these sausages with the addition of chitosan as a bio-preservative was carried out, and also the study developed by Hernández et al. (2013), who showed the influence of flaxseed meal as an extender agent in croquettes made from Nile tilapia. Likewise, alternatives have been developed for products made from red tilapia filleting waste (HLEAP; VELASCO, 2010; HLEAP; RODRÍGUEZ, 2015) to provide a protein-rich diet, diversify the raw materials used and develop aquaculture in this country.
The use of plant based flours as extenders is a good alternative in the development of meat and fish products (AIKING, 2011). They can replace varying proportions of meat protein in the formulation of sausages, seeking, amongst other things, to take advantage of the functionality, take legal aspects into account, preserve the nutritional value, consider the quality of the protein and control production costs (YAÑEZ, 2009). Quinoa (Chenopodium quinoa W.) flour contains high protein and carbohydrate levels, a relatively high concentration of insoluble dietary fibre and a low fat content (PEÑA et al., 2015; NOWAK et al., 2016). The functional properties of quinoa flour, such as the water and lipid binding capacities, the emulsification capacity, the texture and the nutritional value make it suitable for use as an extender in meat and fish products (ABUGOCH, 2009).

The scientific literature contains many studies on red tilapia in terms of its biological, reproductive and captive breeding aspects, but there are very few studies on its use and transformation into food products for human consumption. Therefore, the objective of this research was to analyse the influence of quinoa flour on the physicochemical properties of sausages made from red tilapia fillet waste, during storage under refrigeration $\left(2^{\circ} \mathrm{C} \pm 2^{\circ} \mathrm{C}\right)$ and sale, including the texture and oxidative stability.

\section{Material and methods}

Red tilapia fillet waste and quinoa flour were used to develop this research. The first was obtained from a fish processing company in the city of Cali (Vale del Cauca), frozen in $500 \mathrm{~g}$ batches in polyethylene bags. The quality was guaranteed according to the sanitation standards of the National Institute of Surveillance and Food and Drug Administration - INVIMA of Colombia. The filleting wastes were kept frozen until used. Table 1 shows the fish sausage formula. Two types or sausage treatments were used with the addition of quinoa flour at concentrations of $10 \mathrm{~g} / \mathrm{kg}$ and $20 \mathrm{~g} / \mathrm{kg}$, along with a control batch without the addition of flour, based on the research developed by Purohit et al. (2016). The sausages were manufactured with a weight of $60 \mathrm{~g}$, the weight of a commercial sausage. The additives were purchased in Cali (Valle del Cauca) and corresponded to meat that is traditionally used for food inputs. The quinoa flour was used as an extender agent ( $92 \%$ of its particles passed through a $12 x x$ sieve, equivalent to a diameter of 102 microns), acquired from Molinos Nariño, Pasto, Colombia. The nutritional composition of the quinoa flour was starch $-610 \mathrm{~g} / \mathrm{kg}$, 
Physicochemical analysis of frankfurter type sausages made with red tilapia fillet waste (Oreochromis $s p$ ) and quinoa flour (Chenopodium quinoa W.)

Zapata, J. I. H.; Pava, G. C. R.

Table 1. Formulation of the fish sausages.

\begin{tabular}{|c|c|c|c|}
\hline Ingredients & $\begin{array}{c}\text { Treatment } 1 \\
(\%)\end{array}$ & $\begin{array}{c}\text { Treatment } 2 \\
(\%)\end{array}$ & $\begin{array}{c}\text { Treatment } \\
\text { Control } \\
(\%)\end{array}$ \\
\hline $\begin{array}{l}\text { Minced red tilapia } \\
\text { filleting wastes }\end{array}$ & 60.00 & 60.00 & 60.00 \\
\hline Pork fat & 6.00 & 6.00 & 6.00 \\
\hline Salt (NaCl) & 2.00 & 2.00 & 2.00 \\
\hline Ascorbic acid & 0.50 & 0.50 & 0.50 \\
\hline $\begin{array}{l}\text { Sodium } \\
\text { Polyphosphate }\end{array}$ & 2.00 & 2.00 & 3.00 \\
\hline Nitrite & 1.00 & 1.00 & 1.00 \\
\hline Sugar & 1.50 & 1.50 & 1.50 \\
\hline White pepper & 2.00 & 2.00 & 2.00 \\
\hline Paprika & 2.00 & 2.00 & 2.00 \\
\hline Cumin & 0.50 & 0.50 & 0.50 \\
\hline Laurel & 0.50 & 0.50 & 0.50 \\
\hline Oregano & 0.50 & 0.50 & 0.50 \\
\hline Powdered onion & 0.50 & 0.50 & 0.50 \\
\hline Powdered garlic & 1.00 & 1.00 & 1.00 \\
\hline Potato starch & 3.00 & 0.00 & 6.00 \\
\hline Wheat starch & 7.00 & 0.00 & 14.00 \\
\hline Quinoa flour & 10.00 & 20.00 & 0.00 \\
\hline Total & 100.00 & 100.00 & 100.00 \\
\hline
\end{tabular}

protein - $195 \mathrm{~g} / \mathrm{kg}$, moisture - $72 \mathrm{~g} / \mathrm{kg}$, lipids - $24 \mathrm{~g} / \mathrm{kg}$, raw dietary fibre $-8 \mathrm{~g} / \mathrm{kg}$ and ash $21 \mathrm{~g} / \mathrm{kg}$, according to data provided by the manufacturer.

The sausages were prepared in the Laboratory of Meat technology of the National University of Colombia - Palmira, using a formulation that was previously developed, validated and standardized at the University (HLEAP; VELASCO, 2012). The fillet waste from the tilapia and the pork fat were cut using stainless steel knives. These raw materials were then transferred to a Javar ${ }^{\circledR} \mathrm{M} 121 \mathrm{Mill}$ (Javar, Bogotá, Colombia) equipped with a $6 \mathrm{~mm}$ diameter grid. Subsequently, the ingredients were homogenized with fish and fat in a Hobart 84181-D cutter (Corporation Troy, Ohio, USA). Once the emulsion was obtained, the stuffing process was started in an Javar ${ }^{\circledR}$ EM 30 beaker (Javar, Bogotá, Colombia) using $22 \mathrm{~mm}$ diameter artificial casing (Amicel ${ }^{\circledR}$ Alico S.A., Cali, Colombia). The sausages were portioned with a length of $12 \mathrm{~cm}$, corresponding to an approximate weight of $60 \mathrm{~g}$, and left for 15 minutes at $80{ }^{\circ} \mathrm{C}$, as measured using a Chektemp HI 98501 needle thermometer (HANNA Instruments Ltda., Leighton Buzzard Bedfordshire, England), in a scalding tank. They were then subjected to thermal shock in cold water for 10 minutes. Finally, they were packed in a vacuum sealing machine EGARVAC S.C.P. Basic B (Vacarisses, Barcelona, Spain) and stored at refrigeration temperature $\left(2{ }^{\circ} \mathrm{C} \pm 2{ }^{\circ} \mathrm{C}\right)$.

The sausages were subjected to the respective analyses 72 hours after they were made, remaining in the vacuum packages under refrigeration $\left(2^{\circ} \mathrm{C} \pm 2^{\circ} \mathrm{C}\right)$ up to that moment. The tests carried out on the sausages included the proximate chemical composition, $\mathrm{pH}$, instrumental colour, lipid oxidation, water holding capacity (WHC), water binding ability (WVA) and cooking yield, along with instrumental texture.

The proximate chemical composition was determined using the methods of the Association of Official Analytical Chemists - AOAC: $n^{\circ} 934.01$ for moisture, $n^{\circ} 940.25$ for total protein with a factor of $\mathrm{N} \times 6.25, \mathrm{n}^{\circ} 942.05$ for fat, and $\mathrm{n}^{\circ}$ 942.05 for ash (LATIMER, 2012). The dietary fibre was determined according to the methodology proposed by Morales et al. (2012) and the energy value was measured as total calories kcal/100 $\mathrm{g}$ according to the pump calorimeter method of Berthelot-Mahler. The nitrites were quantified in parts per million, according to the AOAC chemical method $n^{\circ}$ 973.31. All the analyses were carried out in triplicate for each sausage treatment evaluated, including the sausage control. The results are shown as the average plus standard deviation.

Water holding capacity (WHC) and water binding ability (WBA) were measured as proposed by Pietrasik and Janz, (2009). A centrifugal force of $20,000 \times \mathrm{g}$ was applied for 10 minutes to the raw sausages, and the weight difference was used to calculate the WHC. Protein swelling in the raw sausages was calculated and expressed as the water binding ability, the ability to bind distilled water added externally. These measurements were taken on freshly prepared sausages to assess the influence of the quinoa flour content on the moisture binding characteristics. The WBA was defined as the ability of the sausages to bind externally added distilled water.

The cooking yield was measured as the difference in weight of the sausages before and after cooking (water temperature $80^{\circ} \mathrm{C}$, internal temperature of sausages $72^{\circ} \mathrm{C}$ ), divided by the sample weight before heating, expressed as a percentage. The tests were carried out in triplicate and the results averaged for the statistical analysis.

The colour parameters were measured using a Konica Minolta brand colorimeter, model CR-400, with illuminant D65 and $2^{\circ}$ observation angle (calibrated with a plate equipment with reference values $Y=89.5, x=0.3176$ and $y=0.3340$ ) for each batch of sausages. The CIElab coordinates were measured on days $0,1,3$ and 6 , and expressed in terms of lightness $L^{*}\left(L^{*}=0\right.$ for black and $L^{*}=100$ for white), and chromaticity parameters $a^{*}$ (green [-] and red [+]) and $b^{*}$ (blue [-] and yellow [+]). From these parameters, the coordinates $\mathrm{C}$ (chroma) and $\mathrm{H}$ (hue) were calculated. The colour measurements were taken in triplicate on the surface of each of the sausages evaluated. The results were averaged for the statistical analyses.

The lipid oxidation products were measured as the thiobarbituric acid reactive substances (TBARS), according to the method of John et al. (2005). The tests 
Physicochemical analysis of frankfurter type sausages made with red tilapia fillet waste (Oreochromis $s p$ ) and quinoa flour (Chenopodium quinoa W.)

Zapata, J. I. H.; Pava, G. C. R.

were carried out in triplicate on days 1, 3 and 6 and the results averaged for the statistical analyses.

The texture profile analysis and shear stress test were carried out using a Shimadzu EZTest EZ-S Universal Tester texture meter in order to observe the changes in texture in relation to the concentration of quinoa flour added. For the analysis of the texture profile, $1.5 \mathrm{~cm}$ thick sausage slices were left to stand for one hour at room temperature in a polyethylene bag to prevent moisture loss. Double compression was used at $75 \%$ strain (normal stress) and a crosshead speed of $1 \mathrm{~mm} / \mathrm{s}$, with a timeout of 5 seconds between compressions. The parameters analysed were hardness $\left(\mathrm{kg} \mathrm{m} \mathrm{s}^{-2}\right)$, elasticity (dimensionless), cohesiveness (dimensionless) and chewability ( $\mathrm{kg} \mathrm{mm}$ ). The shear force was determined using the Warner Bratzler blade method (AMSA, 2015). For this procedure, a cut was made in the middle of the sausage. The conditions were: spindle speed $2 \mathrm{~mm} / \mathrm{s}$ and $30 \mathrm{~mm}$ displacement. The results were taken from the peak (maximum force) resulting from shear force.

The statistical analysis was carried out using the SAS version (SAS Institute, Inc. ISA). A completely randomised design was used for the parameters of proximal chemical composition, $\mathrm{pH}, \mathrm{WHC}, \mathrm{WBA}$, cooking yield and the texture analysis, and analysed using one-way ANOVA. The parameters analysed in each treatment were applied for quinoa flour concentrations of $0 \mathrm{~g} / \mathrm{kg}, 10 \mathrm{~g} / \mathrm{kg}$ and $20 \mathrm{~g} / \mathrm{kg}$. For the parameters of lipid oxidation (TBARS) and colour, for which measurements were taken on different days of storage, a completely balanced factorial design was used, considering the storage days and quinoa flour concentrations and using two-way ANOVA. Three replicates were prepared for the processing of each treatment and averaged for the statistical analyses.

\section{Results and discussion}

As the amount of quinoa flour increased, so the $\mathrm{pH}$ of the sausages increased (Table 2). The samples containing $20 \mathrm{~g} / \mathrm{kg}$ quinoa flour had a significantly higher $\mathrm{pH}$ of 5.68 , as compared to the control sausage 5.61 $(p<0.05)$. Adding quinoa flour also led to a significant increase in the protein, ash and dietary fibre contents in the tilapia sausages analysed $(p<0.05)$. The moisture content decreased significantly with the addition of quinoa flour $(p<0.05)$.

When comparing the results presented by Peña et al. (2015), who worked with pork sausages with the addition of quinoa flour, the sausages made in this study had higher protein and moisture contents but lower fat contents. Similarly, the work done by Granados et al. (2013), who worked with sausages based on tuna processing by-products (Scombridae thunus), showed that the protein and moisture contents were lower than those found in the present study. It was found that the addition of quinoa flour led to an increase in dry mass in terms of protein, ash and fibre and a decrease in moisture in the sausages prepared with tilapia fillet wastes.

The WHC and WBA of the fresh sausages significantly increased $(p<0.05)$ with the addition of quinoa four at a concentration of $10 \mathrm{~g} / \mathrm{kg}$, as compared to the control sausage (Table 3 ).

However, the addition of quinoa flour at a concentration of $20 \mathrm{~g} / \mathrm{kg}$ caused a significant decrease in the WHC and WBA values. A similar trend was seen for the cooking yield values, which increased significantly $(p<0.05)$ for the sausages with $10 \mathrm{~g} / \mathrm{kg}$ addition of quinoa flour as compared to the control sausage, but decreased with an increase in the concentration of quinoa flour to $20 \mathrm{~g} / \mathrm{kg}$. It is known that non-meat ingredients affect the WHC and WBA values due to electrostatic repulsion, as well as the $\mathrm{pH}$ of meat products (DETIENNE; WICKER, 1999). Both water and other non-meat ingredients interact with the structure of fish muscle, leading to alterations in protein functionality and final product performance.

Specifically, the addition of $10 \mathrm{~g} / \mathrm{kg}$ quinoa flour increased the WHC, WBA and cooking yield, which may be due to the absorption of water by the myofibrils, reducing the water loss during cooking (BERTRAM et al., 2008;

Table 2. Proximate composition, energy value, nitrite content and $\mathrm{pH}$ of tilapia fillet waste sausages with three concentrations of quinoa flour ${ }^{(1)}$

\begin{tabular}{lrrr}
\multirow{3}{*}{$\begin{array}{c}\text { Proximate } \\
\text { composition }\end{array}$} & \multicolumn{3}{c}{ Quinoa flour } \\
\cline { 2 - 4 } \multicolumn{1}{c}{$\mathbf{g} / \mathbf{k g})$} & $\begin{array}{c}\text { Treatment } \\
\text { Control }\end{array}$ & \multicolumn{1}{c}{ Treatment 1 } & Treatment 2 \\
Moisture & $64.55 \pm 0.38^{\mathrm{a}}$ & $61.97 \pm 0.23^{\mathrm{ab}}$ & $61.02 \pm 0.36^{\mathrm{b}}$ \\
Protein & $17.92 \pm 0.33^{\mathrm{c}}$ & $18.13 \pm 0.54^{\mathrm{b}}$ & $18.41 \pm 0.46^{\mathrm{a}}$ \\
Lipid & $2.64 \pm 0.12^{\mathrm{a}}$ & $2.68 \pm 0.15^{\mathrm{a}}$ & $2.70 \pm 0.13^{\mathrm{a}}$ \\
Ash & $1.99 \pm 0.14^{\mathrm{b}}$ & $2.00 \pm 0.13^{\mathrm{ab}}$ & $2.02 \pm 0.12^{\mathrm{a}}$ \\
Carbohydrate & $12.35 \pm 0.25^{\mathrm{a}}$ & $13.78 \pm 0.29^{\mathrm{a}}$ & $14.21 \pm 0.30^{\mathrm{a}}$ \\
Dietary fibre & $0.12 \pm 0.08^{\mathrm{c}}$ & $0.14 \pm 0.09^{\mathrm{b}}$ & $0.15 \pm 0.08^{\mathrm{a}}$ \\
Energy value, & $197.34 \pm 1.26^{\mathrm{a}}$ & $199.68 \pm 1.40^{\mathrm{a}}$ & $200.75 \pm 1.42^{\mathrm{a}}$ \\
kcal/100 g & & & \\
Nitrite, ppm & $126.08 \pm 0.24^{\mathrm{a}}$ & $126.12 \pm 0.29^{\mathrm{a}}$ & $126.65 \pm 0.26^{\mathrm{a}}$ \\
pH & $5.61 \pm 0.77^{\mathrm{b}}$ & $5.65 \pm 0.64^{\mathrm{ab}}$ & $5.68 \pm 0.68^{\mathrm{a}}$ \\
\hline
\end{tabular}

(1) Means ( $n=3$ ) with different letters in the same row are significantly different at $5 \%$. Each value indicates the mean of the measurement \pm standard error.

Table 3. The effect of adding quinoa flour on the different parameters of tilapia fillet waste sausages ${ }^{(1)}$

\begin{tabular}{cccc}
$\begin{array}{c}\text { Quinoa Flour } \\
(\mathbf{g} / \mathbf{k g})\end{array}$ & WHC & WBA & $\begin{array}{c}\text { Cooking } \\
\text { yield }\end{array}$ \\
\hline 0 & $14.57 \pm 1.12^{\mathrm{b}}$ & $33.54 \pm 1.83^{\mathrm{b}}$ & $33.54 \pm 1.83^{\mathrm{b}}$ \\
10 & $17.19 \pm 0.98^{\mathrm{a}}$ & $43.28 \pm 0.97^{\mathrm{a}}$ & $43.28 \pm 0.97^{\mathrm{a}}$ \\
20 & $9.66 \pm 1.46^{\mathrm{c}}$ & $34.02 \pm 1.23^{\mathrm{b}}$ & $34.02 \pm 1.23^{\mathrm{a}}$ \\
\hline
\end{tabular}

(1) Means $(n=3)$ with different letters in the same column are significantly different at $5 \%$. Each value indicates the mean of the measurements \pm standard error. WHC = Water holding capacity; WBA $=$ Water binding ability. All values reported on a percent weight basis (wet weight basis). 
Physicochemical analysis of frankfurter type sausages made with red tilapia fillet waste (Oreochromis sp) and quinoa flour (Chenopodium quinoa W.)

Zapata, J. I. H.; Pava, G. C. R.

YANG et al., 2016). An increase in the cooking yield was observed for the tilapia fillet waste sausages with $10 \mathrm{~g} / \mathrm{kg}$ quinoa flour, which may have been due to the interaction between the flour and the fish protein. The results agree with data reported by Barretto et al. (2015), who worked with Bologna type sausage containing wheat fibre, oat fibre and inulin. In this research adding quinoa flour at a concentration of $10 \mathrm{~g} / \mathrm{kg}$ gave the highest cooking yield, with the greatest number of water-protein interactions at this level. Adding quinoa flour at higher concentrations resulted in increased protein-protein interactions, and hence starches or other hydrophilic molecules, in this case quinoa flour, are used to improve the water binding properties, which coincides with the data published by Pietrasik and Janz (2009); Chattong et al. (2015); and Shao et al. (2016).

The effect of the relationship between the storage days and the concentration of quinoa flour significantly affected the colour parameters (Figure 1). After 6 days of storage, the sausages with $10 \mathrm{~g} / \mathrm{kg}$ of quinoa flour were significantly lighter (higher values for $L^{*}$ ). The sausages with $20 \mathrm{~g} / \mathrm{kg}$ of quinoa flour were significantly lighter than the sausage control on days 0 and 1 , but were significantly darker on day $6(p<0.05)$. Generally, all of the samples were significantly darker on day $0(p<0.05)$. No clear trend for changes in the red colour $\left(\mathrm{a}^{*}\right)$ was noted, although the values were significant $(p<0.05)$. The sausages with quinoa flour added at both concentrations became significantly less yellow up to day $3(p<0.05)$. On day 6 , the sausages with quinoa flour at a concentration of $20 \mathrm{~g} / \mathrm{kg}$ were less yellow than those with a concentration of $10 \mathrm{~g} / \mathrm{kg}$. No significant variation in the value for yellow was observed in the control sausages. The hue values $(\mathrm{H})$ decreased significantly $(p<0.05)$ from day 0 to day 6 for the samples with added quinoa flour, with higher values for the $10 \mathrm{~g} / \mathrm{kg}$ concentration. A reduction in hue indicates that the samples became redder. However, the control sausages had a significant counter trend $(p<0.05)$ for hue. The chroma (c) coordinate indicated that the colour intensity decreased significantly $(p<0.05)$ in the sausages with the addition of quinoa flour, as compared to the control sausages. Finally, the addition of quinoa flour led to decreased sausage paling.

The $10 \mathrm{~g} / \mathrm{kg}$ quinoa flour treatment showed higher values for lightness $\left(L^{*}\right)$ and yellowness $\left(b^{*}\right)$ than the control and the $20 \mathrm{~g} / \mathrm{kg}$ concentration, and generally a decreasing trend was observed during the 6 days of storage. The colour parameters showed no significant changes in terms of redness $\left(a^{*}\right)$ and virtually no visual differences in the darkening of the sausages in the treatments
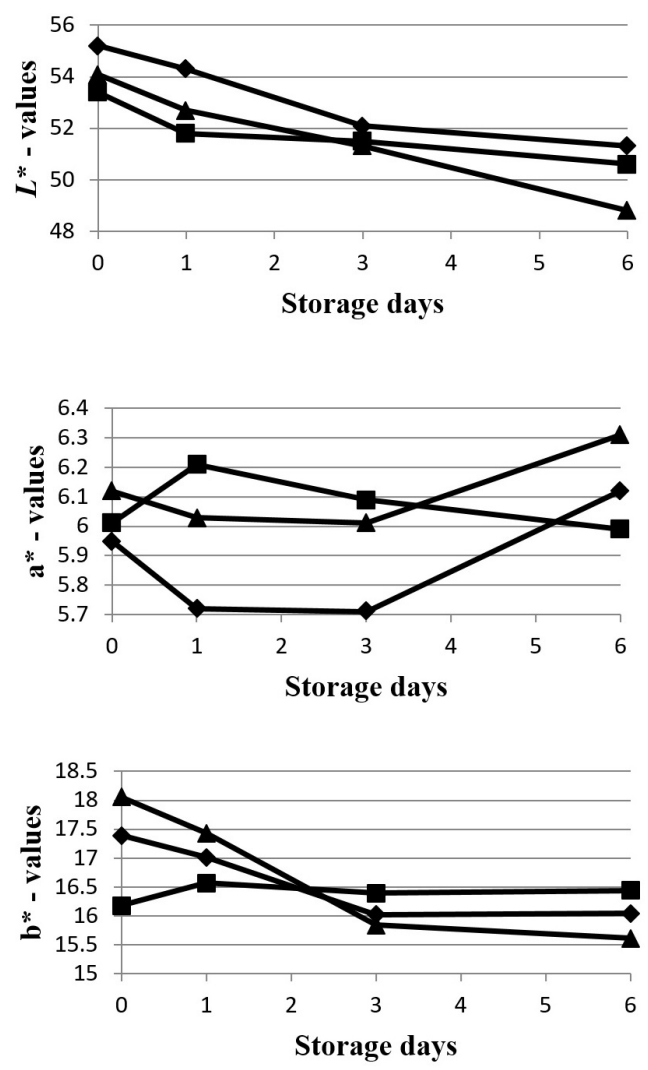

Quinoa flour (QF) concentrations: (অ) $0 \mathrm{~g} / \mathrm{kg} \mathrm{QF},(\boldsymbol{)}) 10 \mathrm{~g} / \mathrm{kg} \mathrm{QF}$ and $(\boldsymbol{\Delta}) 20 \mathrm{~g} / \mathrm{kg} \mathrm{QF}$

Figure 1. $L^{*}, a^{*}$ and $b^{*}$ parameters for the sausages elaborated. 
Physicochemical analysis of frankfurter type sausages made with red tilapia fillet waste (Oreochromis sp) and quinoa flour (Chenopodium quinoa W.)

Zapata, J. I. H.; Pava, G. C. R.

analysed. The incorporation of non-meat ingredients can mitigate differences in the colour of meat products. Changes in the colour parameters have been reported by Pinzón-Zárate et al. (2015) for sausages containing oily peach palm extracts (Bactris gasipaes), as well as by Hyun-Wook et al. (2015) who worked with sausages containing wheat fibre coloured with safflower. The decrease in the WHC and WBA values in the control sausages and in those with the addition of $20 \mathrm{~g} / \mathrm{kg}$ of quinoa flour may have influenced the decrease in the lightness values. High values for these variables tend to show higher values for lightness due to the gloss of the water molecules on the surface of the meat. Akesowan (2008), in a study on pork sausages, showed that the addition of soy protein isolate mixed with konjac flour (Amorphophallus konjac) made the darkest sausages, which explains the sustained fat reductions at the expense of flour ingredients. This is consistent with the results found in the present study. However, the fat content of the three samples was not significantly different, and thus the increased lightness may have been due to the starch present in the quinoa flour.

The lipid oxidation was significantly affected by the interaction between the storage days and the concentration of quinoa flour (Figure 2). On days 1 and 3 , the lipid oxidation significantly increased $(p<0.05)$ with the addition of quinoa flour and the increase showed a steady trend.

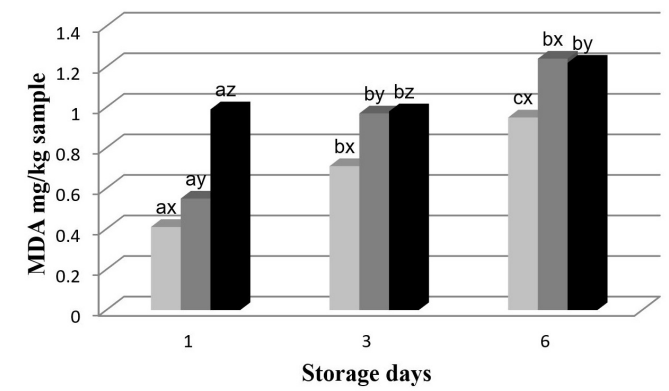

Quinoa flour (QF) concentrations: ( $\square$ ) 0 g/kg QF, ( $\square$ ) 10 g/kg QF, ( $\square$ ) 20 g/kg

Figure 2. Lipid oxidation in sausages measured after 6 days storage, expressed as equivalents of malondialdehyde (MDA), in $\mathrm{mg} / \mathrm{kg}$. The relationship 'storage days vs. quinoa flour concentration' was significant $(p<0.05)$. Means $(n=3)$ with different letters $(a-c)$ on a given day and different letter $(x-z)$ at different concentrations are significantly different at $5 \%$.
The samples containing $20 \mathrm{~g} / \mathrm{kg}$ quinoa flour showed more lipid oxidation than those with $10 \mathrm{~g} / \mathrm{kg}$ quinoa flour and the control sausages. On day 6 , only the samples with $20 \mathrm{~g} / \mathrm{kg}$ quinoa flour showed significantly higher lipid oxidation. In the samples with quinoa flour, lipid oxidation did not significantly increase after day 3 , but it did for the control sausages.

The scientific literature has reported that the proteins from some legumes (soy, lentils and beans, amongst others) have antioxidant properties (DÁVILA et al., 2003; ZOU et al., 2011). However, in this study, the addition of quinoa flour was associated with an increase in oxidation of the sausages. The mineral content of the quinoa flour included pro-oxidants (heavy metals) in much higher concentrations than the protein fractions of legumes, such as concentrates or protein isolates (NAVRUZ-VARLI; SANLIER, 2016; LI et al., 2016). From day 3, the MDA values for the sausages with quinoa flour were close to or above $1 \mathrm{mg} / \mathrm{kg}$ of malondialdehyde equivalents. Based on previous studies, products with values below $1 \mathrm{mg} / \mathrm{kg}$ are considered acceptable (MENEGAS et al., 2013; WENJIAO et al., 2014; COBOS et al., 2014). Therefore, one must add antioxidants to the formulations of sausages made with tilapia in order to reduce lipid oxidation and maintain quality.

The texture parameters measured in the sausages are shown in Table 4. Only the hardness increased significantly $(p<0.05)$ with the addition of quinoa flour. The samples containing $20 \mathrm{~g} / \mathrm{kg}$ quinoa flour had the highest hardness values. The shear force increased significantly $(p<0.05)$, with the greatest value seen with the concentration of $20 \mathrm{~g} / \mathrm{kg}$.

As seen from Table 4, the hardness and shear force of the sausages increased with the addition of quinoa flour. The hardness values obtained in this study were lower than those obtained for sausages with the addition of orange peel flour, as reported by Hernández García and Güemes Vera (2010), as well as sausages with the addition of common bean flour, as reported by Albarracín et al. (2010). However, in the present studies, a lower moisture content was observed, which may explain the higher hardness values.

Table 4. Textural properties of the sausages analysed(1).

\begin{tabular}{|c|c|c|c|c|c|}
\hline \multirow[b]{2}{*}{$\begin{array}{l}\text { Quinoa flour } \\
\text { (g/kg) }\end{array}$} & \multicolumn{5}{|c|}{ Instrumental texture analysis } \\
\hline & $\begin{array}{l}\text { Hardness } \\
\left(\mathbf{k g ~ m ~ s}^{-2}\right)\end{array}$ & Cohesiveness & Springiness & $\begin{array}{c}\text { Chewability } \\
\text { (kg mm) }\end{array}$ & Shear force N \\
\hline 0 & $1986 \pm 2.81^{b}$ & $0.366 \pm 0.09^{a}$ & $0.899 \pm 0.54^{a}$ & $7045 \pm 4.34^{b}$ & $9.32 \pm 2.23^{b}$ \\
\hline 10 & $1974 \pm 3.02^{b}$ & $0.343 \pm 0.14^{a}$ & $0.862 \pm 0.57^{a}$ & $6575 \pm 4.27^{b}$ & $12.05 \pm 2.48^{\mathrm{ab}}$ \\
\hline 20 & $2265 \pm 2.98^{a}$ & $0.305 \pm 0.07^{a}$ & $0.801 \pm 0.62^{a}$ & $7344 \pm 4.46^{a}$ & $13.28 \pm 2.37^{a}$ \\
\hline
\end{tabular}

(1) Means $(n=3)$ with different letters in the same column are significantly different at $5 \%$. 
Physicochemical analysis of frankfurter type sausages made with red tilapia fillet waste (Oreochromis $s p$ ) and quinoa flour (Chenopodium quinoa W.)

Zapata, J. I. H.; Pava, G. C. R.

\section{Conclusions}

Incorporating quinoa flour at a concentration of $10 \mathrm{~g} / \mathrm{kg}$ in the formulation of sausages made from tilapia fillet waste led to a lighter colour, improved water holding capacity and water binding ability and the highest cooking yield, without affecting the texture of the sausages. In general, the addition of this flour increased lipid oxidation in the tilapia sausages. A sausage with higher nutritional value was obtained with the protein-rich quinoa flour, and a more rational use was achieved for tilapia fillet waste, which could have positive economic effects for Colombian aquaculture. In the future, studies should be carried out with antioxidants, natural or chemical, other than ascorbic acid, along with physicochemical and sensory testing, which would allow for the use of non-commercial tilapia fillets, an underutilized source of protein, in the production of sausages that have added value through the use of quinoa flour at a concentration of $10 \mathrm{~g} / \mathrm{kg}$.

\section{References}

ABUGOCH, L. E. Quinoa (Chenopodium quinoa Wild): composition, chemistry, nutritional and functional properties. Advances in Food and Nutrition Research, v. 58, p. 1-31, 2009. http://dx.doi. org/10.1016/S1043-4526(09)58001-1. PMid:19878856.

AIKING, H. Future protein supply. Trends in Food Science \& Technology, v. 22, n. 2-3, p. 112-120, 2011. http://dx.doi. org/10.1016/j.tifs.2010.04.005.

AKESOWAN, A. Effect of soy protein isolate on quality of light pork sausages containing konjac flour. African Journal of Biotechnology, v. 7, n. 24, p. 4586-4590, 2008.

ALBARRACÍN, W.; ACOSTA, L. F.; SÁNCHEZ, I. C. Elaboration of a scalded sausage using common bean flour (Phaseolus spp.) as extender. Vitae, v. 17, n. 3, p. 264-271, 2010.

AMERICAN MEAT SCIENCE ASSOCIATION - AMSA. Research guidelines for cookery, sensory evaluation, and instrumental tenderness measurements of meat. 2nd ed. Champaign: AMSA, 2015. v. 1.

AUTORIDAD NACIONAL DE ACUICULTURA Y PESCA - AUNAP. Diagnóstico del estado de la acuicultura en Colombia, Plan de Desarrollo de la Acuicultura Sostenible en Colombia. Bogotá: AUNAP, 2013. Available at: <http://www.aunap.gov. co/wp-content/uploads/2016/04/25-Diagnostico-del-estado-dela-acuicultura-en-Colombia.pdf>. Accessed on: 6 mar. 2016.

BARRETTO, A.; BERTOLDO, M. T.; RODRIGUES, M. A. Effect of the addition of wheat fiber and partial pork fat on the chemical composition, texture and sensory property of low-fat bologna sausage containing inulin and oat fiber. Food Science and Technology, v. 35, n. 1, p. 100-107, 2015. http://dx.doi. org/1590/1678-457X.6496.

BERTRAM, H. C.; MEYER, R. L.; WU, Z.; ZHOU, X.; ANDERSEN, H. J. Water distribution and microstructure in enhanced pork.
Journal of Agricultural and Food Chemistry, v. 56, n. 16, p. 7201-7207, 2008. PMid:18642839. http://dx.doi.org/10.1021/ jf8007426.

CHATTONG, U.; APICHARTSRANGKOON, A.; CHAIKHAM, P.; SUPAVITITPATANA, T.; BELL, A. E. Viscoelastic properties and physicochemical characteristics of pressurized ostrich-meat emulsions containing gum additives. Innovative Food Science \& Emerging Technologies, v. 32, p. 64-69, 2015. http://dx.doi. org/10.1016/j.ifset.2015.07.001.

COBOS, J. E.; SOTO, S.; ALFARO, R. H.; AGUIRRE, G.; RODRIGUEZ, B. R.; GONZÁLEZ, R. Evaluation of quality parameters of sausages made with rabbit meat, lamb and pork, added with wheat fiber. Nacameh, v. 8, n. 1, p. 50-64, 2014.

DÁVILA, M. A.; SANGRONIS, E.; GRANITO, M. Leguminosas germinadas o fermentadas: alimentos o ingredientes de alimentos funcionales. Archivos Latinoamericanos de Nutricion, v. 53, n. 4, p. 348-354, 2003. PMid:15125075.

DETIENNE, N. A.; WICKER, L. Sodium chloride and tripolyphosphate effects on physical and quality characteristics of injected pork loins. Journal of Food Science, v. 64, n. 6, p. 1042-1047, 1999. http://dx.doi.org/10.1111/j.1365-2621.1999.tb12278.x.

FEDERACIÓN COLOMBIANA DE ACUICULTORES - FEDEACUA. Plan de negocio sectorial de la piscicultura colombiana. Bogotá: FEDEACUA, 2015. Available at: <http://www.ptp.com. co/documentos/Plan-de-Negocio-Piscícola-Final-2015.pdf >. Accessed on: 18 dec. 2015.

GRANADOS, C.; GUZMÁN, L.; ACEVEDO, D. Analysis proximal, sensory and texture of elaborated sausages by-products from the tuna processing industry (Scombridae thunus). Información Tecnlógica, v. 24, n. 6, p. 29-34, 2013. http://dx.doi.org/10.4067/ S0718-07642013000600005.

HERNÁNDEZ, B.; PEREIRA, R.; MATSUSHITA, M.; COELHO, A.; BONA, E.; PEREIRA, A. Enhancement of the nutritional status of Nile tilapia (Oreochromis niloticus) croquettes by adding flaxseed flour. Lebensmittel-Wissenschaft + Technologie, v. 54, n. 2 , p. 440-446, 2013. http://dx.doi.org/10.1016/j.Iwt.2013.07.004.

HERNÁNDEZ GARCÍA, S.; GÜEMES VERA, N. Efecto de la adición de harina de cáscara de naranja sobre las propiedades fisicoquímicas, texturales y sensoriales de salchichas cocidas. Nacameh, v. 4, n. 1, p. 23-36, 2010.

HLEAP, J. I.; RODRíGUEZ, G. C. Propiedades texturales y sensoriales de salchichas de tilapia roja (Oreochromis sp.) con adición de harina de chontaduro (Bactris gasipaes). Ingeniería y Desarrollo, v. 33, n. 2, p. 198-215, 2015. http://dx.doi. org/10.14482/inde.33.2.6332.

HLEAP, J. I.; VELASCO, V. A. Analysis of the properties of texture during the storage of sausage made from red tilapia (Oreochromis sp.). Biotecnología en el Sector Agropecuario y Agroindustrial, v. 8, n. 2, p. 46-56, 2010. 
Physicochemical analysis of frankfurter type sausages made with red tilapia fillet waste (Oreochromis sp) and quinoa flour (Chenopodium quinoa W.)

Zapata, J. I. H.; Pava, G. C. R.

HLEAP, J. I.; VELASCO, V. A. Physicochemical parameters during storage of sausages made from red tilapia (Oreochromis sp.).

\section{Biotecnología en el Sector Agropecuario y Agroindustrial,} v. 10, n. 1, p. $42-50,2012$

HYUN-WOOK, K.; KO, H.; DONG, S.; YONG, K.; YOUN, H.; YUN, L.; TAE, J.; YUN, C.; CHEON, K. Wheat fiber colored with a safflower (Cartamus tinctorius L.) red pigment as a natural colorant and antioxidant in cooked sausages. LebensmittelWissenschaft + Technologie, v. 64, n. 1, p. 350-355, 2015. http://dx.doi.org/10.1016/j.Iwt.2015.05.064

JOHN, L.; CORNFORTH, D.; CARPENTER, C.; SORHEIM, O.; PETTEE, B.; WHITTIER, D. Color and thiobarbituric acid values of cooked top sirloin steaks package in modified atmospheres of $80 \%$ oxygen, or 0.4 carbon monoxide, or vacuum. Meat Science, v. 69, n. 3, p. 441-449, 2005. PMid:22062982. http:// dx.doi.org/10.1016/j.meatsci.2004.08.013.

LATIMER, G. W. (Ed.). Official methods of analysis of the Association of Official Analytical Chemists. 19th ed. Gaithersburg: AOAC, 2012.

LI, G.; WANG, S.; ZHU, F. Physicochemical properties of quinoa starch. Carbohydrate Polymers, v. 137, p. 328-338, 2016. PMid:26686137. http://dx.doi.org/10.1016/j.carbpol.2015.10.064.

MENEGAS, L. Z.; PIMENTEL, T. C.; GARCÍA, S.; PRUDENCIO, S. $H$. Dry-fermented chicken sausage produced with inulin and corn oil: physicochemical, microbiological, and textural characteristics and acceptability during storage. Meat Science, v. 93, n. 3, p. 501-506, 2013. PMid:23273457. http://dx.doi.org/10.1016/j. meatsci.2012.11.003.

MORALES, C.; NIETO, A.; QUIROGA, L.; QUICAZÁN, M. Method validation and determination of soluble and insoluble dietary fiber in wheat flour and bread. Vitae, v. 19, n. 1, p. 340-342, 2012.

NAVRUZ-VARLI, S.; SANLIER, N. Nutritional and health benefits of quinoa (Chenopodium quinoa Wild). Journal of Cereal Science, v. 69, p. 371-376, 2016. http://dx.doi.org/10.1016/j. jcs.2016.05.004.

NOWAK, V.; DU, J.; CHARRONDIERE, U. R. Assessment of the nutritional composition of quinoa (Chenopodium quinoa Wild). Food Chemistry, v. 193, p. 47-54, 2016. PMid:26433286. http:// dx.doi.org/10.1016/j.foodchem.2015.02.111.

PEÑA, M.; MÉNDEZ, B.; GUERRA, M.; PEÑA, S. Development of functional meat products: use of quinoa flour. Alimentos, Ciencia e Investigacion, v. 23, n. 1, p. 21-36, 2015.
PIETRASIK, Z.; JANZ, J. A. Influence of freezing and thawing on the hydration characteristics, quality, and consumer acceptance of whole muscle beef injected with solutions of salt and phosphate. Meat Science, v. 81, n. 3, p. 523-532, 2009. PMid:20416596. http://dx.doi.org/10.1016/j.meatsci.2008.10.006.

PINZÓN-ZÁRATE, L. X.; HLEAP-ZAPATA, J. I.; ORDOÑEZ-SANTOS, L. E. Color parameters analysis in Frankfurter sausages with the addition of oily extract of peach palm (Bactris gasipaes). Información Tecnológica, v. 26, n. 5, p. 45-54, 2015. http:// dx.doi.org/10.4067/S0718-07642015000500007.

PUROHIT, A.; REED, C.; MOHAN, A. Development and evaluation of quail breakfast sausage. Lebensmittel-Wissenschaft + Technologie, v. 69, p. 447-453, 2016. http://dx.doi.org/10.1016/j. Iwt.2016.01.058.

SHAO, J.; DENG, Y.; SONG, L.; BATUR, A.; JIA, N.; LIU, D. Investigation the effects of protein hydration states on the mobility water and fat in meat batters by LF-NMR technique. Lebensmittel-Wissenschaft + Technologie, v. 66, p. 1-6, 2016. http://dx.doi.org/10.1016/j.Iwt.2015.10.008.

TAYEL, A. Microbial chitosan as a biopreservative for fish sausages. International Journal of Biological Macromolecules, v. 93, n. Pt A, p. 41-46, 2016. PMid:27565293. http://dx.doi.org/10.1016/j. ijbiomac.2016.08.061.

WENJIAO, F.; YONGKUI, Z.; YUNCHUAN, C.; JUNXIU, S.; YUWEN, Y. TBARS predictive models of pork sausages stored at different temperatures. Meat Science, v. 96, n. 1, p. 1-4, 2014. PMid:23896130. http://dx.doi.org/10.1016/j.meatsci.2013.06.025.

YAÑEZ, J. El uso del huevo como patrón de referencia en el trabajo con los extensores cárnicos. Revista Cubana de Alimentación y Nutrición, v. 19, n. 1, p. 78-80, 2009.

YANG, H.; ZHANG, W.; LI, T.; ZHENG, H.; KHAN, M.; XU, X.; SUN, J.; ZHOU, G. Effect of protein structure on water and fat distribution during meat gelling. Food Chemistry, v. 204, p. 239-245, 2016. PMid:26988498. http://dx.doi.org/10.1016/j. foodchem.2016.01.053.

ZOU, Y.; CHANG, S. K.; GU, Y.; QIAN, S. Y. Antioxidant activity and phenolic compositions of lentil (Lens culinaris var. Morton) extract and its fractions. Journal of Agricultural and Food Chemistry, v. 59, n. 6, p. 2268-2276, 2011. PMid:21332205. http://dx.doi.org/10.1021/jf104640k. 